\title{
ANALYSIS OF NET WORKING CAPITAL TURNOVER AND TOTAL ASSET TURNOVER AGAINST RETURN ON INVESTMENT
}

(Study Case on PT. Indofood Sukses Makmur Tbk and PT. Tiga Pilar Sejahtera

Tbk.

\author{
AYU RAHAYU AND YOYON SUPRIADI \\ STIE KESATUAN
}

\begin{abstract}
Return On Investmet gauges the company's ablity in generating profits with the rest of the available assets in the company. To see how big the resulting profit level over a number of investments that have been implanted.

Return On Investmet can be categorized as bad or good can be reflected in the results of the calculation of Net Working Capital Turnover and Total Asset Turnover. Net Working Capital Turnover and Total Asset Turnover is the independent variable that authors use in research.

This research conducted to test the influence of variabel Net Working Capital Turnover and Total Asset Turnover against Return On Investment. Research done to two companies listed at the IDX in the period 2009-2013.

Research methods using samples to two companies listed in IDX in the period 2009-2013. The data obtained based on the publication of IDX period 2009-2013. Engineering analysis is the simple regression and hypothesis tests using $t$-statistics and $f$-statistic for testing the regression coefficients are simultaneously with $5 \%$ significance level.

The results of the analysis show that variable Net Working Capital Turnover to simultaneously influential significantly to Return On Investment. And the results of the analysis of Total Asset Turnover also simultaneously influential significantly to Return On Investment.
\end{abstract}

Key word: Net Working Capital, Total Asset Turnover, Return on Investment

\section{PENDAHULUAN}

\subsection{Latar Belakang Masalah}

Pada era globalisasi perkembangan dunia usaha berkembang dengan sangat pesat, persaingan ekonomi dan bisnis di tingkat nasional maupun internasional meningkat dengan tajam. Perusahaan sebagai organisasi yang bertujuan memperoleh keuntungan harus memiliki modal kerja guna menunjang kegiatan operasional sehari hari. Dengan modal kerja yang cukup mampu membuat perusahaan mencapai tujuan yang telah ditetapkan. 
Secara umum kondisi kinerja perusahaan dapat diketahui melalui laporan keuangan, melalui laporan keuangan dapat dilakukan Analisa berdasarkan rasio-rasio keuangan. Penggunaan alat Analisa berupa rasio, dapat menunjukan dan memberikan gambaran tentang baik atau buruknya posisi keuangan suatu perusahaan apabila dibandingkan dengan rasio tahun sebelumnya atau dengan perusahaan sejenis lainnya.

Dalam menjalankan sebuah perusahaan, adanya persoalan pengelolaan modal kerja menjadi masalah serius dan merupakan aspek yang sangat penting bagi perusahaan. Banyak perusahaan gulung tikar karena mengalami kondisi tersebut. Karena itu, adanya Analisa atas modal kerja perusahaan sangat penting dilakukan guna mengetahui kondisi modal kerja saat ini kemudian dihubungkan dengan situasi keuangan pada masa yang akan datang. Oleh karena itu, diperlukan adanya perencanan dan pengendalian yang baik dalam pengelolaan modal kerja yang tersedia, dengan asumsi bahwa setiap rupiah dalam modal kerja (kas) yang tertanam dalam aktiva harus dapat digunakan seefisien mungkin sehingga dapat menghasilkan tingkat keuntungan investasi yang maksimal.

Tersedianya modal kerja dapat digunakan dalam operasi tergantung tipe atau sifat dari aktiva lancar yang dimiliki, seperti kas, piutang dan persediaan. Dalam hal ini, modal kerja harus cukup jumlahnya, dalam artian harus mampu membiayai pengeluaran atau operasional perusahaan. Sebab, dengan modal kerja yang cukup akan menguntungkan bagi perusahaan beroperasi secara ekonomis dan efisien.

Kaitannya dengan hal tersebut, pemimpin perusahaan juga harus menjaga agar besarnya modal kerja itu tepat, tidak terlalu besar dan juga tidak terlalu kecil. Sebab, baik terlalu besar maupun terlalu kecil akan berdampak negatif bagi perusahaan. Apabila modal kerja terlalu kecil akan menyebabkan kekurangan modal kerja yang berdampak pada terganggunya kegiatan operasional perusahaan yang pada akhirnya akan menyebabkan hilangnya kesempatan perusahaan untuk memperoleh laba, sebaliknya jika berlebihan menunjukkan adanya dana yang tidak produktif dimana dana yang tersedia tidak dipergunakan secara efektif. Adanya modal kerja yang berlebihan menunjukkan adanya dana yang tidak produktif dan hal ini akan menimbulkan kerugian bagi perusahaan karena tidak mempergunakan kesempatan untuk memperoleh keuntungan melalui dana yang ada, sehingga 
pemilik harus benar-benar dapat mengelola modal kerjanya dengan baik. Untuk itu, perusahaan sebagai organisasi yang profit oriented membutuhkan pengelolaan modal kerja, yang mampu meningkatkan profitabilitas perusahaan.

Selain itu, setiap perusahaan memerlukan modal atau dana untuk menunjang kelangsungan hidup usaha serta pencapaian tujuan perusahaan. Secara kualitasnya, modal kerja merupakan sumber dana berupa kas (net working capital) yang pada hakekatnya diarahkan untuk membiayai kegiatan operasional perusahaan baik dalam jangka pendek maupun jangka panjang. Setiap modal kerja atau dana yang dikeluarkan diharapkan dapat menghasilkan tingkat pengembalian sebesar mungkin melalui hasil penjualan produk dan akan digunakan untuk membiayai kegiatan operasional selanjutnya dan memberikan keuntungan bagi pemilik. Dengan demikian dana tersebut akan terus berputar selama perusahaan masih berjalan.

Perputaran total aset menentukan tingkat efektifitas perusahaan dalam memanfaatkan seluruh asetnya untuk menghasilkan penjualan. Perputaran total aset yang semakin besar mengindikasikan semakin efektif perusahaan mengelola asetnya. Semakin tinggi nilai perputarannya maka akan semakin efektif penggunaan total aset dan semakin tinggi tingkat penjualan sehingga akan memperbesar kemampuan perusahaan dalam menghasilkan laba. Efektifitas dalam penggunaan total asset adalah kunci perusahaan dalam mencapai profitabilitas yang optimum, dengan kemampuan manajemen dalam memanfaatkan total asset yang dimiliki perusahaan memberikan banyak manfaat terhadap perusahaan seperti penggunaan meningkatkan produktifitas, mengefisiensikan biaya dan meningkatkan profitabilitas.

Profitabilitas menunjukkan perbandingan antara laba yang diperoleh perusahaan dengan aktiva atau modal yang dipergunakannnya untuk menghasilkan laba tersebut. Oleh karena itu, profitabilitas yang tinggi menunjukkan semakin efisien perusahaan dalam menjalankan operasinya yang mengindikasikan bahwa perusahaan memiliki kemampuan yang besar dalam menghasilkan laba. Pencapaian profitabilitas yang tinggi tergantung kepada kemampuan pihak manajemen perusahaan dalam merencanakan, mendapatkan, dan memanfaatkan serta mengelola dana-dana seefektif dan seefisien mungkin. Salah satu pengukuran atas kinerja perusahaan tersebut 
adalah dengan mengetahui tingkat pengembalian atas investasi Return on Investment (ROI). Semakin besar ROI semakin baik pula perkembangan perusahaan tersebut dalam mengelola asset yang dimiliki ataupun dalam menghasilkan laba.

Dari uraian diatas penulis sangat tertarik untuk membuat penelitian mengenai pengaruh dari instrument-instrument keuangan yang telah diuraikan diatas. Apa dampak baik dan buruknya untuk perusahaan apabila instrument-instrument keuangan diatas tidak memenuhi criteria yang diinginkan stockholder. Oleh karena itu penulis tertarik untuk membuat skripsi yang berjudul "Analisa modal kerja dan total asset turnover (tato) terhadap return on invesment".

\subsection{Identifikasi Masalah}

Berdasarkan uraian latar belakang diatas, maka permasalahan dapat dirumuskan sebagai berikut :

1. Bagaimana kondisi modal kerja, Total Asset Turnover dan Return on Investment PT. Indofood Sukses Makmur Tbk dan PT. Tiga Pilar Sejathera Tbk selama periode penelitian?

2. Bagaimana modal kerja dan Total Asset Turnover terhadap Return on Investment secara simultan dan parsial PT. Indofood Sukses Makmur Tbk dan PT. Tiga Pilar Sejathera Tbk selama periode penelitian?

3. Bagaimana Pengaruh Modal Kerja (X1) terhadap Return on Investment (ROI) (Y) perusahaan PT. Indofood Sukses Makmur Tbk dan PT. Tiga Pilar Sejathera Tbk selama periode penelitian?

4. Bagaimana Pengaruh Total Assets Turnover (TATO) (X2) terhadap Return on Investment (ROI) (Y) perusahaan PT. Indofood Sukses Makmur Tbk dan PT. Tiga Pilar Sejathera Tbk selama periode penelitian?

5. Bagaimana pengaruh Modal Kerja (X1) dan Total Assets Turnover (TATO) (X2) terhadap return on investment (ROI) ( $\mathrm{Y}$ ) perusahaan PT. Indofood Sukses Makmur Tbk dan PT. Tiga Pilar Sejathera Tbk selama periode penelitian?

\subsection{Tujuan Penelitian}

Tujuan penelitian ini yaitu : 
1. Untuk mengetahui kondisi modal kerja, Total Asset Turnover dan Return on Investment perusahaan PT. Indofood Sukses Makmur Tbk dan PT. Tiga Pilar Sejathera Tbk.

2. Untuk mengetahui modal kerja, Total Asset Turnover dan Return on Invement secara simultan dan parsial perusahaan PT. Indofood Sukses Makmur Tbk dan PT. Tiga Pilar Sejathera Tbk.

3. Untuk mengetahui pengaruh Modal Kerja (X1) terhadap Return on Investment (ROI) $(\mathrm{Y})$ perusahaan selama periode penelitian?

4. Untuk mengetahui pengaruh Total Assets Turnover (TATO) (X2) terhadap Return on Investment (ROI) $(\mathrm{Y})$ perusahaan selama periode penelitian?

5. Untuk mengetahui pengaruh Modal Kerja (X1) dan Total Asset Turnover (TATO) (X2) terhadap Return on Investment (ROI) (Y) perusahaan selama periode penelitian?

\section{TINJAUAN PUSTAKA}

Menurut Menurut Sutrisno (2007:39) "Modal kerja adalah dana yang diperlukan oleh perusahaan untuk memenuhi kebutuhan operasional perusahaan sehari-hari, seperti pembelian bahan baku, pembayaran upah buruh, membayar hutang dan pembayaran lainnya.

Menurut Menurut Stephen A Ross (2010:245) TATO menunjukan efisiensi dimana perusahaan menggunakan seluruh aktivitasnya untuk menghasilkan penjualan. Semakin tinggi perputaran aset, semakin efisien penggunaan aktiva tersebut, dengan kata lain "higer is better". Untuk dapat menggunakan aset yang dimiliki secara efektif dan efisien tentu saja dibutuhkan perencanaan yang matang oleh manajemen perusahaaan. Menurut Menurut Sofyan Syafri Harahap (2008:178) "Return on Investment (ROI) atau yang sering juga disebut dengan "Return on Total Assets" merupakan pengukuran kemampuan perusahaan secara keseluruhan aktiva yang tersedia di dalam perusahaan. Semakin tinggi rasio ini, semakin baik keadaan suatu perusahaan".

\section{Hipotesis Penelitian}

Analisis kuntitatif sebagai berikut :

1. Hipotesis penelitian 1

Modal kerja mempunyai pengaruh yang positif dan signifikan terhadap return on invesment (roi)

2. Hipotesis penelitian

Total asset turnover mempunyai pengaruh yang positif dan signifikan terhadap return on invesment (roi) 
3. Hipotesis penelitian 3

Modal kerja dan total asset turnover mempunyai pengaruh yang positif dan signifikan terhadap return on invesment (roi)

\section{KERANGKA KONSEPTUAL}

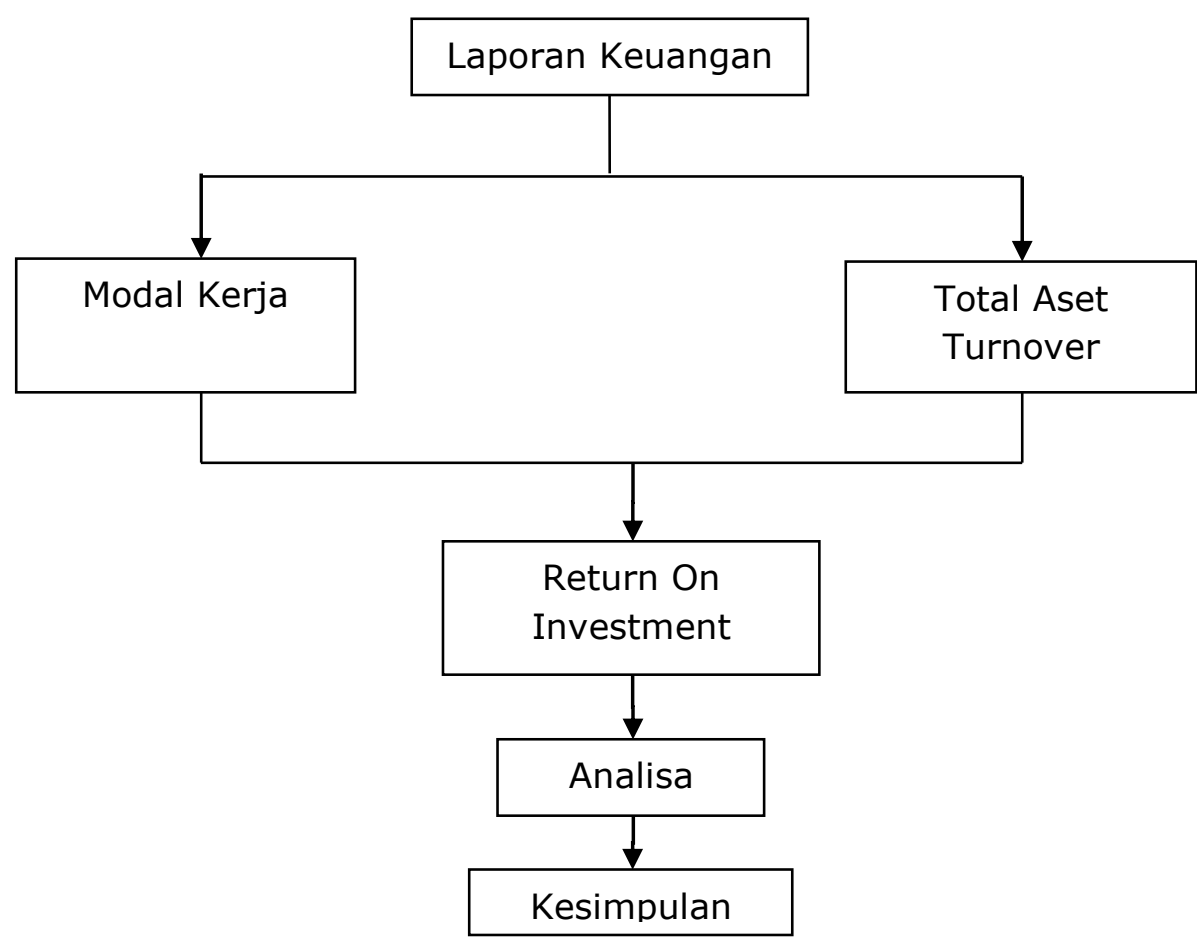

\section{METODOLOGI PENELITIAN}

\section{Lokasi dan Waktu Penelitian}

Lokasi untuk mencari data yang digunakan berada di Laboratorium Bursa Efek Indonesia STIE Kesatuan dan www.idx.co.id. Sampel penelitian ini diambil selama 5 tahun yaitu dari tahun 2009 sampai dengan tahun 2013.

\section{Metode Penelitian}

Metode penelitian yang digunakan dalam penelitian ini adalah metode deskriptif, komparatif dan statistika. Metode ini dipakai dengan alasan penelitian ini bertujuan untuk menjawab pertayaan mengenai Analisa modal kerja dan Total Asset Turnover (TATO) terhadap Retun on Investment (ROI). Metode penelititan ini adalah suatu metode yang dilakukan dengan cara mencari data yang dapat memberikan gambaran yang jelas tentang kinerja keuangan perusahaan. 


\section{Operasional Variabel}

Untuk mempermudah penulisan dalam melakukan penelitian, maka penulis melakukan operasional dan variable-variabel yang berkaitan dengan modal kerja, total asset dan return on investment.

Operasionalisasi dari variable-variabel yang akan diteliti oleh penulis dapat dilihat pada table berikut ini.

Operasional Variable

\begin{tabular}{|c|c|c|}
\hline VARIABEL & INDIKATOR & SKALA UKURAN \\
\hline Modal Kerja & NWCTO & Rasio \\
\hline Total Asset Turn Over & TATO & Rasio \\
\hline Return on Invesment & ROI & Rasio \\
\hline
\end{tabular}

\section{Jenis dan Sumber Data}

Jenis dan sumber data yang digunakan penulis merupakan data sekunder eksternal yang diperoleh melalui studi kepustakaan yang diperoleh dari buku-buku yang terdapat pada STIE Kesatuan Bogor, IDX (Bursa Efek Indonesia), internet dan jurnal-jurnal penelitian terdahulu.

\section{Prosedur Pengumpulan Data}

Dalam melakukan suatu penelitian mengenai Analisa modal kerja dan total assets turnover (TATO) terhadap return on invesmenet. Teknik pengumpulan data yang dipergunakan untuk mendapatkan data penelitian yang dibutuhkan adalah:

a. Studi Kepustakaan (Library Research)

Studi Kepustakaan adalah segala usaha yang dilakukan oleh penulis untuk menghimpul segala informasi yang relevan dengan topik atau masalah yang akan atau sedang diteliti. Informasi itu dapat diperoleh dari buku-buku ilmiah, laporan penelitian, karangan-karangan ilmiah, tesis, dan sumber-sumber tertulis baik secara tercetak dan maupun elektronik lain.

b. Studi Lapangan

Merupakan salah satu alternatif yanng dapat digunakan untuk penelitian seperti berkunjung ke Pojok BEI di STIE Kesatuan maupun media internet dan lain sebagainya sebagai bahan referensi didalam penelitian tersebut. 


\section{Metode Analisis}

Untuk menganalis identifikasi masalah, penulis menggunakan metode Analisa sebagai berikut:

1. Net Working Capital Turnover (NWCTO)

NWCTO $=\frac{\text { sales }}{\text { NetWorkingCapital }}$

Keterangan:

NWCTO = Perputaran Modal Kerja Bersih

Revenues $\quad=$ Pendapatan

Net Working Capital $=$ Modal Kerja Bersih $(N W C=A L-H L)$

2. Total Asset Turnover (TATO)

$$
\text { TATO }=\frac{\text { sales }}{\text { TotalAsset }}
$$

Keterangan:

TATO = Perputaran Total Aset

Sales $\quad=$ Penjualan

Total Asset $\quad=$ Total Aktiva

3. Return on Investment (ROI)

$\mathrm{ROI}=\frac{E A T}{\text { TotalAsset }}$

ROI = Pengembalian Investasi

EAT $\quad=$ Laba Setelah Pajak / Laba Bersih

Total Asset = Total Aktiva Untuk menganalis

\section{HASIL DAN PEMBAHASAN}

Networking Capital (NWCTO) PT. Indofood Sukses Makmur Tbk. Berikut adalah tabel hasil penghitungan networking capital:

\begin{tabular}{|c|c|c|c|c|c|}
\hline \multirow{2}{*}{ Tahun } & Triwulan & Penjualan & $\Delta$ & $\begin{array}{c}\text { Modal } \\
\text { Kerja }\end{array}$ & NWCTO \\
\hline \multirow{2}{*}{2009} & 1 & $\begin{array}{c}\mathrm{Rp} \\
8.911 .259\end{array}$ & - & $\begin{array}{c}\mathrm{Rp} \\
1.604 .500\end{array}$ & 5,55 \\
\cline { 2 - 6 } & 2 & $\begin{array}{c}\mathrm{Rp} \\
18.218 .610\end{array}$ & $747,12 \%$ & $\begin{array}{c}\mathrm{Rp} \\
387.230\end{array}$ & 47,05 \\
\cline { 2 - 6 } & 3 & $\begin{array}{c}\mathrm{Rp} \\
28.204 .813\end{array}$ & $-47,17 \%$ & $\begin{array}{c}\mathrm{Rp} \\
1.134 .805\end{array}$ & 24,85 \\
\cline { 2 - 6 } & 4 & $\begin{array}{c}\mathrm{Rp} \\
37.140 .830\end{array}$ & $-16,79 \%$ & $\begin{array}{c}\mathrm{Rp} \\
1.795 .851\end{array}$ & 20,68 \\
\hline 2010 & 1 & $\begin{array}{c}\mathrm{Rp} \\
9.308 .593\end{array}$ & - & $\begin{array}{c}\mathrm{Rp} \\
2.321 .983\end{array}$ & 4,01 \\
\hline
\end{tabular}




\begin{tabular}{|c|c|c|c|c|c|}
\hline & 2 & $\begin{array}{l}\mathrm{Rp} \\
18.122 .582\end{array}$ & $87,31 \%$ & $\begin{array}{l}\mathrm{Rp} \\
2.413 .487\end{array}$ & 7,51 \\
\hline & 3 & $\begin{array}{l}\mathrm{Rp} \\
28.308 .902\end{array}$ & $27,16 \%$ & $\begin{array}{l}\mathrm{Rp} \\
2.964 .730\end{array}$ & 9,55 \\
\hline & 4 & $\begin{array}{l}\mathrm{Rp} \\
38.403 .360\end{array}$ & $-60,64 \%$ & $\begin{array}{l}\mathrm{Rp} \\
10.218 .876\end{array}$ & 3,76 \\
\hline \multirow{4}{*}{2011} & 1 & $\begin{array}{l}\mathrm{Rp} \\
10.761 .188\end{array}$ & - & $\begin{array}{l}\mathrm{Rp} \\
10.613 .188\end{array}$ & 1,01 \\
\hline & 2 & $\begin{array}{l}\mathrm{Rp} \\
21.843 .659\end{array}$ & $102,22 \%$ & $\begin{array}{l}\mathrm{Rp} \\
10.653 .628\end{array}$ & 2,05 \\
\hline & 3 & $\begin{array}{l}\mathrm{Rp} \\
33.773 .472\end{array}$ & $45,32 \%$ & $\begin{array}{l}\mathrm{Rp} \\
11.335 .068\end{array}$ & 2,98 \\
\hline & 4 & $\begin{array}{l}\mathrm{Rp} \\
45.332 .256\end{array}$ & $30,37 \%$ & $\begin{array}{l}\mathrm{Rp} \\
11.670 .430\end{array}$ & 3,88 \\
\hline \multirow{4}{*}{2012} & 1 & $\begin{array}{l}\mathrm{Rp} \\
11.826 .831\end{array}$ & - & $\begin{array}{l}\mathrm{Rp} \\
12.466 .356\end{array}$ & 0,95 \\
\hline & 2 & $\begin{array}{l}\mathrm{Rp} \\
24.576 .468\end{array}$ & $105,78 \%$ & $\begin{array}{l}\mathrm{Rp} \\
12.588 .645\end{array}$ & 1,95 \\
\hline & 3 & $\begin{array}{l}\mathrm{Rp} \\
37.254 .978\end{array}$ & $43,04 \%$ & $\begin{array}{l}\mathrm{Rp} \\
13.340 .911\end{array}$ & 2,79 \\
\hline & 4 & $\begin{array}{l}\mathrm{Rp} \\
50.059 .427\end{array}$ & $36,61 \%$ & $\begin{array}{l}\mathrm{Rp} \\
13.122 .428\end{array}$ & 3,81 \\
\hline \multirow{4}{*}{2013} & 1 & $\begin{array}{l}\mathrm{Rp} \\
12.856 .168\end{array}$ & - & $\begin{array}{l}\mathrm{Rp} \\
11.863 .138\end{array}$ & 1,08 \\
\hline & 2 & $\begin{array}{l}\mathrm{Rp} \\
26.862 .418\end{array}$ & $176,91 \%$ & $\begin{array}{l}\mathrm{Rp} \\
8.951 .402 \\
\end{array}$ & 3,00 \\
\hline & 3 & $\begin{array}{l}\mathrm{Rp} \\
41.279 .123\end{array}$ & $10,69 \%$ & $\begin{array}{l}\mathrm{Rp} \\
12.427 .318\end{array}$ & 3,32 \\
\hline & 4 & $\begin{array}{l}\mathrm{Rp} \\
57.731 .998\end{array}$ & $33,77 \%$ & $\begin{array}{l}\mathrm{Rp} \\
12.993 .188\end{array}$ & 4,44 \\
\hline
\end{tabular}

Berdasarkan penjelasan diatas maka nampak bahwa modal kerja PT. Indofood sukses makmur Tbk. selama lima tahun periode penelitian menunjukan kondisi yang sangat efektif dan efisien kecuali pada triwulan I tahun 2012 perusahaan berada dalam kondisi paling rendah dalam perputaran modal kerjanya 0,95x .

Total Asset PT. Indofood Sukses Makmur Tbk.

Berikut adalah tabel hasil penghitungan Total Asset turnover (Tato):

\begin{tabular}{|c|c|l|c|l|c|}
\hline Tahun & Triwulan & Penjualan & $\Delta$ & Total Aset & TATO \\
\hline \multirow{3}{*}{2009} & 1 & $\begin{array}{l}\mathrm{Rp} \\
8.911 .259\end{array}$ & - & $\begin{array}{l}\mathrm{Rp} \\
40.832 .133\end{array}$ & 0,22 \\
\cline { 2 - 6 } & 2 & $\begin{array}{l}\mathrm{Rp} \\
18.218 .610\end{array}$ & $107,00 \%$ & $\begin{array}{l}\mathrm{Rp} \\
40.327 .646\end{array}$ & 0,45 \\
\cline { 2 - 6 } & \multirow{2}{*}{3} & $\begin{array}{l}\mathrm{Rp} \\
28.204 .813\end{array}$ & $53,66 \%$ & $\begin{array}{l}\mathrm{Rp} \\
40.629 .575\end{array}$ & 0,69 \\
\hline
\end{tabular}




\begin{tabular}{|c|c|c|c|c|c|}
\hline & 4 & $\begin{array}{l}\mathrm{Rp} \\
37.140 .830\end{array}$ & $32,49 \%$ & $\begin{array}{l}\mathrm{Rp} \\
40.382 .953\end{array}$ & 0,92 \\
\hline \multirow{4}{*}{2010} & 1 & $\begin{array}{l}\mathrm{Rp} \\
9.308 .593\end{array}$ & - & $\begin{array}{l}\mathrm{Rp} \\
41.447 .211\end{array}$ & 0,22 \\
\hline & 2 & $\begin{array}{l}\mathrm{Rp} \\
18.122 .582\end{array}$ & $91,79 \%$ & $\begin{array}{l}\mathrm{Rp} \\
42.072 .894\end{array}$ & 0,43 \\
\hline & 3 & $\begin{array}{l}\mathrm{Rp} \\
28.308 .902\end{array}$ & $53,25 \%$ & $\begin{array}{l}\mathrm{Rp} \\
42.885 .629\end{array}$ & 0,66 \\
\hline & 4 & $\begin{array}{l}\mathrm{Rp} \\
38.403 .360\end{array}$ & $23,06 \%$ & $\begin{array}{l}\mathrm{Rp} \\
47.275 .955\end{array}$ & 0,81 \\
\hline \multirow{4}{*}{2011} & 1 & $\begin{array}{l}\mathrm{Rp} \\
10.761 .188\end{array}$ & - & $\begin{array}{l}\mathrm{Rp} \\
48.836 .807\end{array}$ & 0,22 \\
\hline & 2 & $\begin{array}{l}\mathrm{Rp} \\
21.843 .659\end{array}$ & $88,66 \%$ & $\begin{array}{l}\mathrm{Rp} \\
52.544 .013\end{array}$ & 0,42 \\
\hline & 3 & $\begin{array}{l}\mathrm{Rp} \\
33.773 .472\end{array}$ & $53,13 \%$ & $\begin{array}{l}\mathrm{Rp} \\
53.055 .095\end{array}$ & 0,64 \\
\hline & 4 & $\begin{array}{l}\mathrm{Rp} \\
45.332 .256\end{array}$ & $32,89 \%$ & $\begin{array}{l}\mathrm{Rp} \\
53.585 .933\end{array}$ & 0,85 \\
\hline \multirow{4}{*}{2012} & 1 & $\begin{array}{l}\mathrm{Rp} \\
11.826 .831\end{array}$ & - & $\begin{array}{l}\mathrm{Rp} \\
56.095 .140\end{array}$ & 0,21 \\
\hline & 2 & $\begin{array}{l}\mathrm{Rp} \\
24.576 .468\end{array}$ & $105,28 \%$ & $\begin{array}{l}\mathrm{Rp} \\
56.784 .109\end{array}$ & 0,43 \\
\hline & 3 & $\begin{array}{l}\mathrm{Rp} \\
37.254 .978\end{array}$ & $50,71 \%$ & $\begin{array}{l}\mathrm{Rp} \\
57.115 .131\end{array}$ & 0,65 \\
\hline & 4 & $\begin{array}{l}\mathrm{Rp} \\
50.059 .427\end{array}$ & $29,37 \%$ & $\begin{array}{l}\mathrm{Rp} \\
59.324 .207\end{array}$ & 0,84 \\
\hline \multirow{4}{*}{2013} & 1 & $\begin{array}{l}\mathrm{Rp} \\
12.856 .168\end{array}$ & - & $\begin{array}{l}\mathrm{Rp} \\
60.553 .536\end{array}$ & 0,21 \\
\hline & 2 & $\begin{array}{l}\mathrm{Rp} \\
26.862 .418\end{array}$ & $94,77 \%$ & $\begin{array}{l}\mathrm{Rp} \\
64.959 .585\end{array}$ & 0,41 \\
\hline & 3 & $\begin{array}{l}\mathrm{Rp} \\
41.279 .123\end{array}$ & $35,79 \%$ & $\begin{array}{l}\mathrm{Rp} \\
73.512 .792\end{array}$ & 0,56 \\
\hline & 4 & $\begin{array}{l}\mathrm{Rp} \\
57.731 .998\end{array}$ & $31,66 \%$ & $\begin{array}{l}\mathrm{Rp} \\
78.092 .789\end{array}$ & 0,74 \\
\hline
\end{tabular}

Berdasarkan penjelasan diatas maka nampak bahwa Total Asset (Tato) PT. Indofood sukses makmur Tbk. selama lima tahun periode penelitian menunjukan kondisi yang cuku efektif dan efisien dalam memanfaatkan seluruh asset yang dimiliki. kecuali pada triwulan I tahun 2012 dan 2013 perusahaan hanya mampu melakukan perputaran total asset nya sebanyak $0,21 x$.

Return on Invesment (ROI) PT. Indofood Sukses Makmur Tbk Berikut adalah tabel hasil penghitungan Return on investment (ROI)

\begin{tabular}{|c|c|c|c|c|c|}
\hline Tahun & Triwulan & EAT & $\Delta$ & Total Aset & ROI \\
\hline \multirow{4}{*}{2009} & 1 & Rp235.646 & - & Rp 40.832.133 & $0,58 \%$ \\
\cline { 2 - 6 } & 2 & Rp1.203.519 & $417 \%$ & Rp 40.327 .646 & $2,98 \%$ \\
\cline { 2 - 6 } & 3 & Rp2.180.504 & $80 \%$ & Rp 40.629.575 & $5,37 \%$ \\
\cline { 2 - 6 } & 4 & Rp2.856.781 & $32 \%$ & Rp 40.382.953 & $7,07 \%$ \\
\hline
\end{tabular}




\begin{tabular}{|c|c|c|c|c|c|}
\hline \multirow{4}{*}{2010} & 1 & Rp842.717 & - & Rp 41.447.211 & $2,03 \%$ \\
\hline & 2 & Rp1.795.697 & $110 \%$ & Rp 42.072.894 & $4,27 \%$ \\
\hline & 3 & Rp2.830.993 & $55 \%$ & Rp 42.885.629 & $6,60 \%$ \\
\hline & 4 & Rp3.934.808 & $26 \%$ & Rp 47.275.955 & $8,32 \%$ \\
\hline \multirow{4}{*}{2011} & 1 & Rp1.228.989 & - & Rp 48.836.807 & $2,52 \%$ \\
\hline & 2 & Rp2.552.089 & $93 \%$ & Rp 52.544.013 & $4,86 \%$ \\
\hline & 3 & Rp3.723.567 & $44 \%$ & Rp 53.055.095 & $7,02 \%$ \\
\hline & 4 & Rp4.891.673 & $30 \%$ & Rp 53.585.933 & $9,13 \%$ \\
\hline \multirow{4}{*}{2012} & 1 & Rp1.286.484 & - & Rp 56.095.140 & $2,29 \%$ \\
\hline & 2 & Rp2.526.132 & $94 \%$ & Rp 56.784.109 & $4,45 \%$ \\
\hline & 3 & Rp3.804.976 & $50 \%$ & Rp 57.115.131 & $6,66 \%$ \\
\hline & 4 & Rp4.779.446 & $21 \%$ & Rp 59.324.207 & $8,06 \%$ \\
\hline \multirow{4}{*}{2013} & 1 & Rp946.116 & - & Rp 60.553.536 & $1,56 \%$ \\
\hline & 2 & Rp2.067.726 & $104 \%$ & Rp 64.959.585 & $3,18 \%$ \\
\hline & 3 & Rp2.467.501 & $5 \%$ & Rp 73.512.792 & $3,36 \%$ \\
\hline & 4 & Rp3.414.886 & $30 \%$ & Rp 78.092.789 & $4,37 \%$ \\
\hline
\end{tabular}

Berdasarkan penjelasan diatas maka nampak bahwa Return on investment PT. Indofood Sukses Makmur Tbk selama lima tahun periode penelitian menunjukan kondisi perusahaan yang cukup bagus dalam memanfaatkan total asset yang dimiliki untuk menghasilkan laba, terlihat pada Triwulan IV pada tahun 2011 perusahaan mampu menghasilkan Roi sebesar 9,13\% namun pada Triwulan I 2009 perusahaan hanya menghasilkan Roi yang hanya rendah sebesar $0,58 \%$.

Networking Capital (NWCTO) PT. Tiga Pilar Sejahtera Tbk

Berikut adalah tabel hasil penghitungan networking capital :

\begin{tabular}{|c|c|c|c|c|c|}
\hline Tahun & Triwulan & Penjualan & $\Delta$ & Modal Kerja & NWCTO \\
\hline \multirow{4}{*}{2009} & 1 & Rp 115.661 & - & $\begin{array}{l}\mathrm{Rp} \\
22.705\end{array}$ & 5,09 \\
\hline & 2 & Rp 286.038 & $391,30 \%$ & $\begin{array}{l}\mathrm{Rp} \\
11.429\end{array}$ & 25,03 \\
\hline & 3 & Rp 405.363 & $-83,97 \%$ & $\begin{array}{l}\mathrm{Rp} \\
101.023\end{array}$ & 4,01 \\
\hline & 4 & Rp 533.194 & $107,67 \%$ & $\begin{array}{l}\mathrm{Rp} \\
63.986\end{array}$ & 8,33 \\
\hline \multirow{2}{*}{2010} & 1 & Rp 122.839 & - & $\begin{array}{l}\mathrm{Rp} \\
80.936\end{array}$ & 1,52 \\
\hline & 2 & Rp 302.744 & $62,27 \%$ & $\begin{array}{c}\mathrm{Rp} \\
122.928\end{array}$ & 2,46 \\
\hline
\end{tabular}




\begin{tabular}{|c|c|c|c|c|c|}
\hline & 3 & Rp 439.858 & $-6,54 \%$ & $\begin{array}{l}\mathrm{Rp} \\
191.091\end{array}$ & 2,30 \\
\hline & 4 & Rp 705.219 & $107,41 \%$ & $\begin{array}{l}\mathrm{Rp} \\
147.714\end{array}$ & 4,77 \\
\hline \multirow{4}{*}{2011} & 1 & Rp 365.211 & - & $\begin{array}{l}\mathrm{Rp} \\
133.863\end{array}$ & 2,73 \\
\hline & 2 & Rp 746.165 & $18,19 \%$ & $\begin{array}{l}\mathrm{Rp} \\
231.399\end{array}$ & 3,22 \\
\hline & 3 & Rp 1.131.097 & $410,97 \%$ & $\begin{array}{l}\mathrm{Rp} \\
68.649\end{array}$ & 16,48 \\
\hline & 4 & Rp 1.752.802 & $-86,94 \%$ & $\begin{array}{l}\mathrm{Rp} \\
814.745\end{array}$ & 2,15 \\
\hline \multirow{4}{*}{2012} & 1 & Rp 577.239 & - & $\begin{array}{l}\mathrm{Rp} \\
812.964\end{array}$ & 0,71 \\
\hline & 2 & Rp 1.285.891 & $133,43 \%$ & $\begin{array}{l}\mathrm{Rp} \\
775.839\end{array}$ & 1,66 \\
\hline & 3 & Rp 1.952.519 & $123,96 \%$ & $\begin{array}{l}\mathrm{Rp} \\
526.010\end{array}$ & 3,71 \\
\hline & 4 & Rp 2.747.623 & $125,71 \%$ & $\begin{array}{l}\mathrm{Rp} \\
327.943\end{array}$ & 8,38 \\
\hline \multirow{4}{*}{2013} & 1 & Rp 854.604 & - & $\begin{array}{l}\mathrm{Rp} \\
454.270\end{array}$ & 1,88 \\
\hline & 2 & Rp 1.783.575 & $7,48 \%$ & $\begin{array}{l}\mathrm{Rp} \\
882.096\end{array}$ & 2,02 \\
\hline & 3 & Rp 2.944.806 & $28,95 \%$ & $\begin{array}{l}\mathrm{Rp} \\
1.129 .439\end{array}$ & 2,61 \\
\hline & 4 & Rp 4.056.735 & $48,42 \%$ & $\begin{array}{l}\mathrm{Rp} \\
1.048 .280\end{array}$ & 3,87 \\
\hline
\end{tabular}

Berdasarkan penjelasan diatas maka nampak bahwa modal kerja PT. Tiga Pilar Sejahtera Tbk. selama lima tahun periode penelitian menunjukan kondisi yang sangat efektif dan efisien kecuali pada triwulan I tahun 2012 perusahaan berada dalam kondisi paling rendah dalam perputaran modal kerjanya $0,71 \mathrm{x}$.

Total Asset PT. Tiga Pilar Sejahtera Tbk.

Berikut adalah tabel hasil penghitungan Total Asset Turnover (Tato) 


\begin{tabular}{|c|c|c|c|c|c|}
\hline \multirow{4}{*}{2009} & 1 & $\begin{array}{l}\mathrm{Rp} \\
115.661\end{array}$ & - & Rp 1.054 .125 & 0,11 \\
\hline & 2 & $\begin{array}{l}\mathrm{Rp} \\
286.038\end{array}$ & $141,37 \%$ & Rp 1.080 .049 & 0,26 \\
\hline & 3 & $\begin{array}{l}\mathrm{Rp} \\
405.363\end{array}$ & $35,55 \%$ & Rp 1.129.191 & 0,36 \\
\hline & 4 & $\begin{array}{l}\mathrm{Rp} \\
533.194\end{array}$ & $10,26 \%$ & Rp 1.347 .036 & 0,40 \\
\hline \multirow{4}{*}{2010} & 1 & $\begin{array}{l}\mathrm{Rp} \\
122.839\end{array}$ & - & Rp 1.352 .683 & 0,09 \\
\hline & 2 & $\begin{array}{l}\mathrm{Rp} \\
302.744\end{array}$ & $127,56 \%$ & Rp 1.465 .022 & 0,21 \\
\hline & 3 & $\begin{array}{l}\mathrm{Rp} \\
439.858\end{array}$ & $41,21 \%$ & Rp 1.507 .333 & 0,29 \\
\hline & 4 & $\begin{array}{l}\mathrm{Rp} \\
705.219\end{array}$ & $24,77 \%$ & Rp 1.936.949 & 0,36 \\
\hline \multirow{4}{*}{2011} & 1 & $\begin{array}{l}\mathrm{Rp} \\
365.211\end{array}$ & - & Rp 1.936 .153 & 0,19 \\
\hline & 2 & $\begin{array}{l}\mathrm{Rp} \\
746.165\end{array}$ & $89,75 \%$ & Rp 2.084.701 & 0,36 \\
\hline & 3 & $\begin{array}{l}\mathrm{Rp} \\
1.131 .097\end{array}$ & $30,87 \%$ & Rp 2.414 .688 & 0,47 \\
\hline & 4 & $\begin{array}{l}\mathrm{Rp} \\
1.752 .802\end{array}$ & $4,22 \%$ & Rp 3.590.309 & 0,49 \\
\hline \multirow{4}{*}{2012} & 1 & $\begin{array}{l}\mathrm{Rp} \\
577.239\end{array}$ & - & Rp 3.520 .817 & 0,16 \\
\hline & 2 & $\begin{array}{l}\mathrm{Rp} \\
1.285 .891\end{array}$ & $112,07 \%$ & Rp 3.698 .477 & 0,35 \\
\hline & 3 & $\begin{array}{l}\mathrm{Rp} \\
1.952 .519\end{array}$ & $46,99 \%$ & Rp 3.820 .679 & 0,51 \\
\hline & 4 & $\begin{array}{l}\mathrm{Rp} \\
2.747 .623\end{array}$ & $39,02 \%$ & Rp 3.867 .576 & 0,71 \\
\hline \multirow{3}{*}{2013} & 1 & $\begin{array}{l}\mathrm{Rp} \\
854.604\end{array}$ & - & Rp 3.931 .076 & 0,22 \\
\hline & 2 & $\begin{array}{l}\mathrm{Rp} \\
1.783 .575\end{array}$ & $88,25 \%$ & Rp 4.358.046 & 0,41 \\
\hline & 3 & $\mathrm{Rp}$ & $51,68 \%$ & Rp 4.743.929 & 0,62 \\
\hline
\end{tabular}




\begin{tabular}{|l|l|l|l|l|l|} 
& 2.944 .806 & & & \\
\cline { 2 - 5 } & 4 & $\begin{array}{l}\mathrm{Rp} \\
4.056 .735\end{array}$ & $30,18 \%$ & $\operatorname{Rp~5.020.284}$ & 0,81 \\
\hline
\end{tabular}

Berdasarkan penjelasan diatas maka nampak bahwa Total Asset (Tato) PT. Indofood sukses makmur Tbk. selama lima tahun periode penelitian menunjukan kondisi yang cuku efektif dan efisien dalam memanfaatkan seluruh asset yang dimiliki. kecuali pada triwulan I tahun 2010 perusahaan hanya mampu melakukan perputaran total asset nya sebanyak 0,09x.

\section{Return on Invesment (ROI) PT. Tiga Pilar Sejahtera Tbk}

Berikut adalah tabel hasil penghitungan Return on investment (ROI)

\begin{tabular}{|c|c|c|c|c|c|c|}
\hline Tahun & Triwulan & & EAT & $\Delta$ & Total Aset & ROI \\
\hline \multirow{4}{*}{2009} & 1 & $\mathrm{Rp}$ & 5.624 & - & $\mathrm{Rp} 1.054 .125$ & $0,5 \%$ \\
\hline & 2 & $\mathrm{Rp}$ & 19.775 & $243,18 \%$ & Rp 1.080 .049 & $1,8 \%$ \\
\hline & 3 & $\mathrm{Rp}$ & 23.246 & $12,44 \%$ & Rp 1.129 .191 & $2,1 \%$ \\
\hline & 4 & $\mathrm{Rp}$ & 37.823 & $36,39 \%$ & Rp 1.347 .036 & $2,8 \%$ \\
\hline \multirow{4}{*}{2010} & 1 & $\mathrm{Rp}$ & 5.792 & - & Rp 1.352 .683 & $0,4 \%$ \\
\hline & 2 & $\mathrm{Rp}$ & 24.779 & $295,01 \%$ & Rp 1.465 .022 & $1,7 \%$ \\
\hline & 3 & $\mathrm{Rp}$ & 23.298 & $-8,62 \%$ & Rp 1.507 .333 & $1,5 \%$ \\
\hline & 4 & $\mathrm{Rp}$ & 79.443 & $165,36 \%$ & Rp 1.936.949 & $4,1 \%$ \\
\hline \multirow{4}{*}{2011} & 1 & $\mathrm{Rp}$ & 25.072 & - & Rp 1.936.153 & $1,3 \%$ \\
\hline & 2 & $\mathrm{Rp}$ & 48.498 & $79,65 \%$ & Rp 2.084.701 & $2,3 \%$ \\
\hline & 3 & $\mathrm{Rp}$ & 80.324 & $42,99 \%$ & Rp 2.414 .688 & $3,3 \%$ \\
\hline & 4 & $\mathrm{Rp}$ & 149.951 & $25,55 \%$ & Rp 3.590.309 & $4,2 \%$ \\
\hline \multirow{4}{*}{2012} & 1 & $\mathrm{Rp}$ & 53.937 & - & Rp 3.520 .817 & $1,5 \%$ \\
\hline & 2 & & 126.956 & $124,07 \%$ & Rp 3.698 .477 & $3,4 \%$ \\
\hline & 3 & $\mathrm{Rp}$ & 195.712 & $49,23 \%$ & $\mathrm{Rp} \quad 3.820 .679$ & $5,1 \%$ \\
\hline & 4 & $\mathrm{Rp}$ & 253.664 & $28,04 \%$ & Rp 3.867 .576 & $6,6 \%$ \\
\hline \multirow{4}{*}{2013} & 1 & $\mathrm{Rp}$ & 75.160 & - & Rp 3.931 .076 & $1,9 \%$ \\
\hline & 2 & $\mathrm{Rp}$ & 161.632 & $93,98 \%$ & $\mathrm{Rp} 4.358 .046$ & $3,7 \%$ \\
\hline & 3 & $\mathrm{Rp}$ & 250.618 & $42,44 \%$ & Rp 4.743.929 & $5,3 \%$ \\
\hline & 4 & $\mathrm{Rp}$ & 346.728 & $30,73 \%$ & Rp 5.020 .284 & $6,9 \%$ \\
\hline
\end{tabular}

Berdasarkan penjelasan diatas maka nampak bahwa Return on investment PT. Indofood Sukses Makmur Tbk selama lima tahun periode penelitian menunjukan kondisi perusahaan yang cukup bagus dalam 
memanfaatkan total asset yang dimiliki untuk menghasilkan laba, terlihat pada Triwulan IV pada tahun 2013 perusahaan mampu menghasilkan Roi sebesar 6,9\% namun pada Triwulan I, 2010 perusahaan hanya menghasilkan Roi yang hanya rendah sebesar $0,4 \%$.

\section{KESIMPULAN DAN SARAN}

\section{Kesimpulan}

Berdasarkan penelitian yang telah dilakukan oleh penulis, menggunakan data laporan keuangan PT. Indofood Sukses Makmur, Tbk., dan PT. Tiga Pilar, Tbk., dengan periode penelitian selama lima tahun, mulai dari tahun 2009 sampai dengan tahun 2013 maka kesimpulan penulis dari hasil penelitian ini memberikan solusi pengaruh dari 2 (dua) variabel independent terhadap Return on Investment (ROI) adalah sebagai berikut:

1. Hasil penelitian yang telah dilakukan penulis didapat modal kerja PT. Indofood Sukses Makmur, Tbk., tidak berpengaruh signifikan terhadap Return on Investment (ROI) hal ini terjadi karena hasil uji $t$ pada perusahaan ini memberikan informasi bahwa t hitung sebesar 0,112, sedangkan $\mathrm{t}$ tabel pada tingkat kepercayaan $\alpha$ (alpha) sebesar $5 \%$ atau 0,05 dan derajat bebas (df) sebesar 18 adalah 2,093. Dapat disimpulkan bahwat hitung lebih kecil dari t tabel atau 0,112<2,093. PT. Tiga Pilar, Tbk., didapat modal kerja yang juga tidak berpengaruh signifikan terhadap Return on Investment (ROI) hal ini terjadi karena hasil uji $t$ memberikan informasi bahwa $t$ hitung sebesar 0,064, sedangkan $\mathrm{t}$ tabel pada tingkat kepercayaan $\alpha$ (alpha) sebesar 5\% atau 0,05 dan derajat bebas (df) sebesar 18 adalah 2,093. Dapat disimpulkan bahwa t hitung lebih kecil dari t tabel atau 0,064 2,093. Tidak signifikannya perusahaan ini karena adanya perbedaan di penelitian terdahulu yang tahunnya berbeda, adanya perbedaan pula pada sektor perusahaan yang di teliti penulis. Hal ini dikarenakan perusahaan memiliki hutang yang cukup besar yang belum dibayarkan kepada pihak lain. Yang secara langsung mempengaruhi proporsisi di neraca laporan keuangan perusahaan.

2. Hasil penelitian yang telah dilakukan penulis didapat bahwa Total Asset Turnover (TATO) PT. Indofood Sukses Makmur, Tbk., berpengaruh signifikan terhadap Return on Investment (ROI) karena hasil uji $t$ memberikan informasi bahwa $\mathrm{t}$ hitung sebesar 6,491, sedangkan $\mathrm{t}$ tabel pada tingkat kepercayaan $\alpha$ (alpha) sebesar 5\% atau 0,05 dan derajat bebas (df) sebesar 18 adalah 2,093. Dapat disimpulkan $t$ 
hitung lebih besar dari t tabel atau 6,491> 2,093. Pada PT. Tiga Pilar, Tbk pun didapat Total Asset Turnover (TATO) berpengaruh signifikan terhadap Return on Investment (ROI) hal ini terjadi karena hasil uji t memberikan informasi bahwa $t$ hitung sebesar 6,121 sedangkan $t$ tabel pada tingkat kepercayaan $\alpha$ (alpha) sebesar $5 \%$ atau 0,05 dan derajat bebas (df) sebesar 18 adalah 2,093.

3. Hasil penelitian yang telah dilakukan penulis didapat bahwa modal kerja dan total asset turnover (TATO) PT. Indofood Sukses Makmur, Tbk., berpengaruh signifikan terhadap return on investment (ROI) karena diperolehnya $f$ hitung sebesar $21,600>$ dari $f$ tabel sebesar 4,414 dengan nilai signifikansinya sebesar 0,000 atau $0 \%$ yang berada di bawah a (alpha) sebesar 5\% atau 0,05. Pada PT. Tiga Pilar, Tbk didapat bahwa modal kerja dan total asset turnover (TATO) berpengaruh signifikan terhadap return on investment (ROI) karena diperolehnya $f$ hitung sebesar 18,199 > dari $f$ tabel sebesar 4,414 dengan nilai signifikansinya sebesar 0,000 atau $0 \%$ yang berada di bawah $\alpha$ (alpha) sebesar $5 \%$ atau 0,05 .

\subsection{Saran}

1. Berdasarkan analisis dan pembahasan yang telah dijelaskan pada $B A B$ IV, maka penulis menyarankan kepada PT. Indofood Sukses Makmur, Tbk dan PT. Tiga Pilar, Tbk yang sebaiknya mengurangi hutang jangka pendek untuk menstabilkan proporsi hutang lancar dalam neraca laporan keuangan perusahaan.

2. Berdasarkan analisis dan pembahasan yang telah dijelaskan pada BAB IV, maka penulis menyarankan kepada PT. Indofood Sukses Makmur, Tbk dan PT. Tiga Pilar, Tbk untuk lebih optimal dalam hal kinerja keuangan perusahaan kedepannya guna menjadikan perusahaan jauh lebih baik dari segi laporan keuangan dan laba yang dihasilkan dari tahun ke tahunnya.

3. Bagi peneliti selanjutnya agar memperbanyak data peneliti sehingga hasil penelitian akan lebih akurat.

\section{DAFTAR PUSTAKA}


Astagfirli, Ratih Gayatri. 2012. Pengaruh Perputaran Modal Kerja, Perputaran Total Aset Dan Rasio Utang Terhadap Rentabilitas Pada Perusahaan Properti Dan Real Estate Yang Terdaftar Di Bursa Efek Indonesia Periode 2007-2011, Jurusan Akuntansi, Fakultas Ekonomi, Universitas Maritim Raja Ali Haji.

Brigham, Eugene F., dan Houston, Joel F. 2010. Fundamental of Financial Statement, Salemba Empat, Jakarta.

Carl S. Warren, James M. Reeve dan Philip E. Fess. 2005. Pengantar Akuntansi, Salemba Empat, Jakarta.

Hanum, Encik Latifah. 2008. Pengaruh Kebijakan Modal Kerja Terhadap Return On Investment Pada Industri Rokok Yang Terdaftar Di Bursa Efek Indonesia, Jurusan Akuntansi, Fakultas Ekonomi, Universitas Sumatera Utara.

Harahap, Sofyan Syafri. 2008. Analisis Kitis Laporan Keuangan, Raja Grafindo Persada, Jakarta.

Jerry J. Weygandt, Donald E. Kieso, Paul D. Kimmel. 2007. Accounting Principle, John Wiley \& Sons.

Jumingan. 2007. Analisis Laporan Keuangan, Bumi Aksara, Jakarta.

Mulyana, M. and Puspitasari, R., 2014. Analisis Faktor-faktor Yang Membentuk Minat Berwirausaha Siswa SMK di Kota Bogor.

Mulyana, M. and Maulana, M., 2013. Pengaruh Pelayanan Terhadap Kepuasan Pelanggan dan Implikasinya Terhadap Citra Perusahaan. Jurnal IImiah Manajemen Kesatuan, 1(2).

Munawir, S. 2010. Analisa Laporan Keuangan, Liberty, Yogyakarta.

Murhadi, Werner R. 2013. Analisis Laporan Keuangan Proyeksi dan Valuasi Saham, Salemba Empat, Jakarta

Prihadi, Toto. 2013. Analisa Laporan Keuangan Lanjutan, PPM Manajemen, Jakarta.

Priyati, Novi. 2013. Pengantar Akuntansi. Indeks, Jakarta.

Raharjaputra, Hendra S. 2009. Manajemen Keuangan dan Akuntansi, Salemba Empat, Jakarta.

Riyanto, Bambang. 2008. Dasar-dasar Pembelanjaan Perusahaan, Informatika, Bandung.

Ross, Stephen A. 2009. Pengantar Keuangan Perusahaan, Mcgraw Hill Higher Education. 
Ross, Stephen A. 2009. Fundamentals of Corporate Finance, Mcgraw Hill Higher Education.

Rudianto. 2009. Pengantar Akuntansi, Erlangga, Jakarta.

Rudianto. 2012. Pengantar Akuntansi Adaptasi IFRS, Erlangga, Jakarta.

Santoso, Singgih. 2007. Manajemen Keuangan, Elex Media Koputindo, Jakarta.

Sartono, Agus. 2010. Manajemen Keuangan Teori dan Aplikasi. Edisi 4, BPFE, Yogyakarta.

Sawir, Agnes. 2007. Analisis Kinerja Keuangan dan perencanaan Keuangan Perusahaan, Gramedia Pustaka Utama, Jakarta.

Sundjaja, Ridhwan S., Barlian, Inge. 2004. Manajemen Keuangan, Alfabeta, Bandung.

Sunyoto, Danang. 2013. Dasar-dasar Manajemen Keuangan Perusahaan, Caps (K), Yogyakarta.

Sutrisno, Agus. 2009. Teori dan Aplikasi Manajemen Keuangan,Edisi 4, BPFE, Yogyakarta.

Van Horne, James C., WachowitzJr, John M. 2012. Prinsip-Prinsip Manajemen Keuangan 1, Edisi 13, Salemba Empat, Jakarta.

Yulianti, Sri Handaru., Prasetyo, Handoyo. 2007. Dasar-dasar Manajemen Keuangan Internasional, Edisi 2, Andi Publisher, Yogyakarta. 